\title{
MENINGKATKAN HASIL BELAJAR VIRUS MELALUI PEMBELAJARAN KONTEKSTUAL METODE CERAMAH DAN DISKUSI DENGAN TAKTIK BERKELILING MENGHAMPIRI SISWA PADA SISWA KELAS X SMA HANG TUAH 4 SURABAYA
}

\author{
Sunaryo $^{1 *)}$ dan Diana Pratiwi ${ }^{2)}$ \\ ${ }^{1)}$ Pendidikan Biologi Fakultas Bahasa dan Sains Universitas Wijaya Kusuma Surabaya \\ ${ }^{2)}$ SMA Hang Tuah 4 Surabaya \\ "e-mail: sunaryohasan@yahoo.co.id
}

Diterima 2 Januari 2020, Disetujui 12 April 2020, Diterbitkan 15 Mei 2020

\begin{abstract}
The low learning outcomes about Virus of the students of class X IPA Hang Tuah 4 Surabaya, which has been lacking in students' interest, research needs to be done through contextual learning of lecture methods and discussions with the tactics of going around students. This study aims to describe the activities and learning outcomes of the virus through learning. This type of research is Classroom Action Research (CAR), which is carried out in two cycles. The subjects were Grade X IPA 2 Students in Hang Tuah 4 Surabaya High School in the odd semester of the 2019/2020 school year, totaling 34 students. Pre-action data obtained from data that has been documented by the teacher who has taught in the class. The results showed learning activities in the first cycle $61.18 \%$ with sufficient criteria, an increase compared to before the action, the second cycle increased again to $81.76 \%$ with good criteria. While the learning outcomes before the action class average value ranges from 52, the percentage of classical completeness ranges from 50\% (17 of 34 students), after the first cycle of action has increased the grade average value to 77 , the percentage of classical completeness is $79.4 \%$ (27 of 34 students). Furthermore, after the second cycle of action has increased again, the average value of the class to 91 percentage of classical completeness $91.2 \%$ ( 31 of 34 students). The conclusion is the activity and learning outcomes of the students of Class X IPA 2 Hang Tuah 4 Surabaya have increased through the contextual learning of lecture and discussion methods with a tactic to approach students.
\end{abstract}

Keywords : Hasil Belajar Virus, Kontekstual, Ceramah dan Diskusi, Menghampiri Siswa

\section{PENDAHULUAN}

Biologi adalah Ilmu Pengetahuan Alam (IPA) yang mempelajari tentang kehidupan dari segala aspek. Pembelajaran biologi tidak hanya untuk penguasaan pengetahuan yang berupa fakta, konsep, atau prinsip saja, tetapi juga merupakan proses penemuan. Pembelajaran Biologi di SMA diharapkan dapat sebagai wahana bagi siswa untuk mempelajari diri sendiri dan alam sekitarnya untuk dapat dikembangkan lebih lanjut dalam penerapan di dalam kehidupan sehari-hari. Pembelajaran biologi diharapkan dapat meningkatkan iman dan taqwa kepada Tuhan yang Maha Esa yang telah menciptakan alam semesta dan isinya. Materi biologi di SMA sangat kompleks, sehingga diperlukan pembelajaran yang sesuai dengan kompleknya materi tersebut, yang mencakup model, pendekatan, strategi, metode, teknik, dan bahkan taktik, agar tujuan pembelajarannya tercapai.

Kenyataan menunjukkan bahwa kemapuan sains yang di dalamnya mencakup biologi pada siswa Indonesia masih tergolong rendah. Hal ini nampak pada kajian studi Internasional The Programme for International Student Assesment (PISA) tahun 2015 memperoleh skor 403 menduduki perinngkat 62 dari 70 peserta, jauh lebih rendah dibanding negara Asia lainnya yaitu Singapura yang memperoleh skor 556 menduduki peringkat 1 dan Jepang yang memperoleh skor 538 menduduki peringkat 2 (OECD, 2016). Hal itu disebabkan masih rendahnya literasi sains siswa di Indonesia. Kemampuan literasi sains adalah kemampuan mengolah informasi sains dan menerapkannya pada konteks baru (Aditomo dan Felicia, 2018). Konteks baru tersebut 
antara lain adalah isu-isu mutahkir terkait sains yang beredar di masyarakat. Pembelajaran kontekstual diharapkan dapat membantu meningkatkan kemampuan literasi siswa. Pembelajaran kontekstual merupakan konsep belajar, dimana guru mengaitkan antara materi yang diajarkan dengan situasi dunia nyata siswa dan mendorong siswa membuat hubungan antara pengetahuan yang dimilikinya dengan penerapannya dalam kehidupan sehari-hari. Rendahnya Kemampuan IPA-Biologi juga terjadi pada siswa kelas X SMA Hang Tuah 4 Surabaya tepatnya pada materi "Virus". Dari hasil observasi dengan guru kelas $\mathrm{X}$ yang mengajar di kelas tersebut selama 4 tahun terakhir menunjukkan bahwa dari $\mathrm{KKM} \geq 76$, hanya berkisar 50\% siswa yang dapat mencapainya. Pembelajaran yang dilakukan oleh guru selama ini adalah pembelajaran tekstual berpusat pada guru dengan metode ceramah dengan taktik berceramah di depan kelas. Observsasi dilanjutkan dengan sit in di kelas untuk melihat guru dalam mengajar pada kelas, hasilnya menunjukkan bahwa aktifitas siswa dalam mengikuti pelajaran kurang dari yang diharapkan, karena masih banyak yang kurang memperhatikan dan bercakap-cakap dengan temannya.

Melihat fenomena tersebut dilakukan evaluasi untuk mengetahui penyebab aktifitas belajar siswa yang kurang dari yang diharapkan, sehingga berlanjut hasil belajarnya rendah pada materi virus. Akhirnya bisa ditarik kesimpulan bahwa penyebabnya adalah 1). Virus merupakan mikroorganisme, konsep tentang virus bersifat abstrak, meskipun dampak yang ditimbulkan kongkrit, sehingga perlu dicari pendekatan pembelajaran yang tepat 2). Jumlah siswa 34 orang memerlukan tekanan dan intonasi suara guru yang dapat di dengar seluruh siswa 3). Siswa kelas X merupakan masa peralihan dari SMP ke SMA yang masih mudah terpengaruh oleh teman-temannya, sehingga minat dan motivasi belajarnya belum optimal

Untuk mengatasi masalah tersebut perlu dilakukan pembaharuan dalam kegiatan belajar mengajar yaitu melalui pembelajaran kontestual, atau seperangkat pembelajaran yang terdiri atas model pembelajaran berdasarkan masalah, pedekatan kontekstual, strategi inkuiri, metode ceramah dan diskusi dengan taktik berkeliling kelas menghampiri siswa. Model Pembelajaran berdasarkan masalah akan melatih siswa untuk terampil dalam memecahkan masalah. Keterampilan pemecahan masalah merupakan kerampilan dasar yang sangat dibutuhkan siswa (Foshay, 2003), karena dapat membantu siswa membuat keputusan yang tepat, cermat, sistematis, logis, dan dapat mempertimbangkan dari berbagai sudut pandang (Paidi, 2010). Dilaporkan oleh Bahri, dkk (2018), bahwa hasil keterampilan pemecahan masalah biologi materi pertumbuhan dan perkembangan tumbuhan siswa yang dibelajarkan dengan model PBL lebih tinggi dibandingkan dengan yang dibelajarkan menggunakan model Direct Instruction. Pendekatan kontekstual adalah suatu pembelajaran yang mengaitkan antara materi pelajaran dengan dunia siswa secara nyata, sehingga siswa mampu menghubungkan dan menerapkan kompetensinya dengan situasi dunia nyata (Elaini, 2008). Keunggulan pendekatan kontektual telah dilaporakan Setyowati, (2006), bahwa pembelajaran dengan menggunakan pendekatan kontekstual materi tumbuhan berbiji pada siswa SMP lebih efektif daripada pembelajaran yang menggunakan pendekatan konvensional. Strategi Inkuiri merupakan pembelajaran yang melibatkan keaktifan siswa untuk menemukan konsep sendiri. Penerapan strategi inkuiri pada siswa yang memiliki rasa percaya diri tinggi dapat meningkatkan keterampilan proses biologi pada materi pencemaran (Afnidar, 2015).

Metode ceramah adalah metode paling tradisional yang telah lama digunakan dalam dunia pendidikan. Meskipun demikian metode ini tetap saja digunakan dalam pembelajaran modern. Menurut Gulo, (2005), ceramah murni hanya efektif sekitar 15 menit yang pertama, menit-menit berikutnya daya serap siswa mulai menurun. Untuk itu guru perlu berinovasi untuk memadukanya dengan 
metode lain, misalnya metode diskusi kelompok. Tekniknyapun terus berkembang, misalnya menggunakan media gambar atau power poin, dengan pengeras suara, sambil berdiri diatas mimbar, monoton berdiri di depan kelas, atau sambil berkeliling menghampiri siswa.

Metode Ceramah yang dikombinasikan dengan diskusi dengan teknik sambil berkeliling menghampiri siswa dalam penelitian ini, diharapkan dapat mengatasi suara guru yang kurang keras pada kelas yang jumlahnya 34 siswa peralihan dari SMP ke SMA yang masih belum menentukan jati dirinya dalam mendalami bidang ilmu pengetahuan.

\section{METODE PENELITIAN \\ Jenis Penelitian}

Jenis penelitian ini adalah Penelitian Tindakan Kelas (PTK), dengan metode deskriftif yang pelaksanaannya terdiri atas dua siklus, tiap siklus terdiri atas empat tahapan yaitu perencanaan, pelaksanaan, observasi, dan refeksi.

\section{Subyek dan Obyek Penelitian}

Sebagai subyek penelitian ini adalah Siswa kelas X IPA 2 SMA Hang Tuah 4 Surabaya tahun ajaran 2019/2020 yang berjumlah 34 Siswa yang terdiri atas 14 siswa laki-laki dan 20 siswa perempuan. Sedangkan sebagai obyeknya adalah penerapan pembelajaran kontekstual metode ceramah dan diskusi dengan taktik berkeliling menghampiri siswa untuk meningkatkan hasil belajar materi virus

\section{Tempat dan Waktu Penelitian}

Penelitian ini dilaksanakan di kelas $\mathrm{X}$ IPA 2 SMA Hang Tuah 4 di Jalan Bogowonto Nomor 8 Surabaya, pada semester gasal tahun ajaran 2019/2020.

\section{Jenis dan Analisis Data}

Data yang diperoleh dari penelitian ini adalah data kualitatif dan kuantitaif. Data kualitatif adalah data aktifitas belajar siswa yang diperoleh melalui observasi dengan menggunmakan instrumen lembar observasi
(Arikunto, 2006), data tersebut dikuantitatifkan. Sedangkan data kuantitatif adalah data hasil belajar siswa sebelum tindakan yaitu data yang diperoleh dari guru kelas, dan data setelah tindakan siklus I dan II yang diperoleh dengan menggunakan instrumen tes. Hasil Belajar siswa dilihat dari nilai rata-rata kelas dan jumlah siswa yang mencapai nilai KKM. Menurut ketentuan yang ditetapkan di SMA Hang Tuah 4 Surabaya untuk mata pelajaran IPA adalah $\geq 76$.

Hasil belajar klasikal dihitung dengan menggunakan rumus:

$$
\begin{aligned}
& x=\frac{\sum x}{N} \text { (Sukardi, 2012) } \\
& \mathrm{X} \quad=\text { Nilai rata-rata skor hasil belajar } \\
& \Sigma \mathrm{x}=\text { Jumlah skor hasil belajar } \\
& \mathrm{N}=\text { Jumlah seluruh siswa }
\end{aligned}
$$

Ketuntasan belajar klasikal dihitung dengan menggunakan rumus:

$$
\begin{aligned}
& P=\frac{\sum x}{N} \times 100 \% \text { (Sudijono, 2014) } \\
& P=\text { Angka persentase } \\
& \Sigma \mathrm{x}=\text { Jumlah siswa berkategori tuntas } \\
& N=\text { Jumlah seluruh siswa }
\end{aligned}
$$

Data aktifitas dan hasil belajar siswa disajikan dalam tabel, selanjutnya dianalisis secara deskriptif kualitatif.

\section{HASIL DAN PEMBAHASAN}

Penelitian ini menggunakan seperangkat pembelajaran dari model sampai dengan taktik mengajar yang berhubungan, yaitu model pembelajaran berdasarkan masalah, pendekatan kontekstual, strategi inkuiri, metode ceramah dan diskusi dengan taktik sambil berkeliling menghampiri siswa, pada materi virus. Masalah yang didiskusikan siswa adalah masalah yang kontekstual, antara lain 1). Israel memproduksi pembalut yang di dalamnya diberi Virus HIV dengan maksud agar para perempuan Muslimah terinfeksi virus HIV 2). Karyawan Pabrik coca cola yang terinfeksi HIV mengambil darahnya untuk dimasukkan ke dalam bejana yang berisi coca cola sebelum dikemas dalam botiol agar konsumen terular virus HIV. Sebelum di beri permasalahan tersebut siswa 
telah diterangkan tentang sejarah penemuan virus, ciri-ciri, dan replikasi atau perkembangbiakan virus. Siswa diharapkan dapat berdiskusi kelompok menanggapi berita tersebut sampai dapat menyimpulkan apakah berita itu benar atau hoax.

$$
\text { Hasil penelitian penerapan }
$$

pembelajaran kontekstual metode ceramah dan diskusi dengan taktik berkeliling menghampiri siswa pada materi virus yang telah dilakukan di kelas X IPA 2 SMA Hang Tuah 4 Surabaya, sebanyak 2 siklus tertera pada tabel 1 dan 2 di bawah ini.

Tabel 1. Data Aktifitas Belajar Siswa pada Siklus I dan II

\begin{tabular}{ccc}
\hline Siklus & Rata-Rata & Kriteria \\
\hline I & $61,18 \%$ & Cukup \\
II & $81,76 \%$ & Baik \\
\hline
\end{tabular}

Tabel 2. Data Hasil Belajar Siswa Sebelum Tindakan, Siklus I, dan Siklus II

\begin{tabular}{cccc}
\hline $\begin{array}{c}\text { Pra Tindakan dan } \\
\text { Siklus }\end{array}$ & $\begin{array}{c}\text { Nilai Rata- } \\
\text { Rata Kelas }\end{array}$ & $\begin{array}{c}\text { Jumlah Siswa } \\
\text { yang Tuntas }\end{array}$ & $\begin{array}{c}\text { Persentase } \\
\text { Ketuntasan } \\
\text { Belajar Klasikal }\end{array}$ \\
\hline Pra Tindakan & 52 & 17 & $50,0 \%$ \\
Siklus I & 77 & 27 & $79,4 \%$ \\
Siklus II & 91 & 31 & $91,2 \%$ \\
\hline
\end{tabular}

Data aktifitas belajar siswa sebelum tindakan tidak terdokumentasi tetapi dari hasil diskusi dengan guru yang telah lama mengajar di kelas itu dan pengamatan ketika sit in di kelas nampak berbeda jauh, karena aktifitas belajar siklus I mengalami peningkatan yaitu $61,18 \%$ dengan kriteria cukup. Untuk parameter aktifitas belajar siswa menggunakan empat kriteria yaitu $40 \%$ ke bawah tergolong tidak baik, 40\%-55\% kurang, 56\%-75\% cukup, dan76\%-100\% baik (Arikunto, 2006). Hasil belajar pra tindakan terdokumentasi dari tahun ke tahun nilai rata-rata kelas berkisar 52, persentase ketuntasan belajar klasikal berkisar 50\% atau 17 dari 34 siswa. Pada siklus I mengalami kenaikan yang cukup tinggi yaitu menjadi $79,4 \%$ atau 27 dari 34 siswa. Efektifitas pembelajaran kontekstual dengan metode ceramah dan dikusi kelompok dengan taktik berkeliling menghampri siswa pada kelas $X$ IPA 2 SMA Hang Tuah 4 Surabaya dalam meningkat aktifitas belajar yang di ikuti peningkatan hasil belajar siswa sesuai dengan laporan Yulinda dan Ilma, (2018), bahwa pembelajaran kontekstual pada materi mofologi tumbuhan dapat meningkatkan aktifitas belajar guru pra jabatan yang pada akhirnya akan memperkuat pemahamannya.

Untuk memantapkan temuan pada siklus I tersebut selanjutkanya dilakukan persiapan untuk memasuki siklus II, dengan terlebih dahulu dilakukan refleksi. Hasil refleksi diperlukan untuk menyempurnakan materi dalam power point. Hasil tindakan pada silklus II nampak pada tabel 1 dan 2 bahwa aktifitas belajar naik menjadi $81,76 \%$ dengan kriteria baik, demikian juga hasil belajar rata-rat kelas menjadi 91, yang memperoleh nilai tuntas 31 dari 34 siswa atau 91,2\%. Hal tersebut membuktikan bahwa pembelajaran kontekstual mampu meningkatkan aktifitas dan hasil belajar biologi materi virus. Virus adalah mikroorganisma, konsep tentang virus bersifat abstrak, maka pembelajaran dengan pendekatn kontekstual sangant diperlukan. Memberikan permasalahn mutakhir yang berkembang di masyarakat cenderung merangsang siswa berfikir kongkrit . Keunggulan pendekatan kontekstual juga dilaporkan oleh Hasanah, dkk. (2019), bahwa pendekatan kontekstuial dapat meningkatkan hasil belajar rana afektif dan kognitif pada materi kerajaan plante kelas X IPA. Rana 
afektif nya adalah aktifitas belajar sedangkan rana kognitifnya adalah hasil belajar. Aktifitas belajar ketika diskusi kelompok memecahkan masalah akan meningkatkan kedisiplinan, kejujuran, dan penghargaan pada orang lain.

Meningkatnya aktifitas dan hasil belajar siswa pada penelitian tersebut juga disebabkan metode ceramah yang dikombinasikan dengan diskusi kelompok, karena umunya siswa hanya bertahan selam 15 menit untuk mendengarkan ceramah, selanjutnya daya serap siswa akan menurun (Gulo, 2004), dikombinasikan dengan metode diskusi kelompok maka siswa akan terus terlibat dan menyerap materi pelajaran baik dari ceramah maupun diskusi kelompok. Menghampiri siswa sambil berceramah dan membing diskusi kelompok sangat menentukan keberhasilan pembelajaran, karena dengan menghampiri siswa dapat mengendalikan siswa yang terpengaruh temannya untuk bergurau atau ngobrol, siswa akan merasa sungkan sampai takut apabila didekati guru.

Berkeliling menghampiri siswa juga dapat mengatasi gaya bicara guru yang kurang memadahi atau kurang dapat didengar oleh 34 siswa dalam satu kelas, karena seorang guru dalam menyampaikan materi pelajaran harus diupayakan semua siswa mendengar dengan jelas (Sardiman, 2011). Keterampilan menggunakan variasi merupakan salah satu keterampialn mengajar yang harus dikuasi oleh guru (Marno, 2009) Keterampilan tersebut termasuk gaya mengajar yang meliputi variasi suara, variasi gerakan anggota badan,dan variasi perpindahan posisi guru dalam kelas (Jamarah, 2010).

\section{SIMPULAN}

Sebagai simpulan dari penelitian ini adalah pembelajaran kontekstual dengan metode ceramah dan dikusi dengan taktik berkeliling menghampri siswa, dapat Hasanah, U. dkk. 2019, The Effect of Contextual Teaching and Learning (CTL) Based on Lesson Study on the Biology Learning Achievement of High meningkatkan aktivitas dan hasil belajar pada materi virus di kelas X IPA 2 SMA Hang Tuah 4 Surabaya

\section{UCAPAN TERIMA KASIH}

Terima kasih disampaikan kepada Kementerian Riset, Teknologi, dan Pendidikan Tinggi Direktorat Jenderal Pembelajaran dan Kemahasiswaan melaui Program Bantuan Penugasan Dosen di Sekolah (PDS) yang telah membiayai penelitian ini.

\section{DAFTAR PUSTAKA}

Aditomo, A. dan Felicia, N. 2018, Ketimpangan Mutu dan Akses Pendidikan di Indonesia: Potret Berdasarkan Survei PISA 2015, Artikel Kilas Pendidikan Edisi 17, 19 Agustus 2018.

Afnidar, 2015, Pengaruh Strategi Pembelajaran Inkuiri dan Kepercayaan Diri terhadap Keterampilan Proses Sains Biologi Siswa pada Topik Pencemaran Lingkungan di SMA Negeri 1 Mutiara Pidie, ISSN: 2302-1705 JESBIO Vol. IV No. 1, Mei 2015

Arikunto, S. 2006, Prosedur Penelitian Suatu Pendekatan Praktek, Jakarta, Rineka Cipta.

Bahri, A. dkk. 2018, Peran PBL dalam Meningkatkan Keterampilan Pemecahan Masalah Biologi, Jurnal Sainsmat, September 2018, Halaman 114-124 Vol. VII, No. 2 ISSN 2579-5686 (Onine) ISSN 2086-6755 (Cetak), Tersedia di http://ojs.unm.ac.id/index.php/sainsma, Diakses pada Tanggal 20 Oktober 2019.

Elaine B. J. 2008, Contextual Teachning \& Learning: Menjadikan Kegiatan Belajar Mengajar Mengasyikkan dan Bermakna, Terj. Ibnu Setiawan, Bandung, MLC.

Foshay, R. 2003, Principles for Teaching Problem Solving, Indiana University, Plato Learning.

Gulo, W. 2005, Strategi Belajar Mengajar. Jakarta, Grasindo.

School Students, Pancaran Pendidiak FKIP Universitas Jember Vo 8, No 1 (2019) ISSN 0852-601X. e-ISSN 2549838X, Tersedia 
https://pancaranpendidikan.or.id/index. php/pancaran/issue/view/15, Dialkses pada Tanggal 5 Oktober 2019

Jamarah, S.B. dan Zain, A. 2010, Strategi Belajar Mengajar, Jakarta, PT Rineka Cipta.

Marno dan Idris, 2009, Strategi dan Metode Pengajaran, Yogjakarta, Ar-Ruzz Media

OECD, 2016, Programme for International Student Assesment (PISA) Results From PISA 2015, https://www.oecd.org/pisa/PISA-2015Indonesia.pdf, diakses pada Tanggal 20 Oktober 2019.

Paidi. 2010, Model Pemecahan Masalah Dalam Pembelajaran Biologi di SMA. Artikel Seminar Nasional FMIPA Jurusan Pendidikan Biologi Universitas Negeri Yogyakarta.

Sardiman, 2011, Interaksi dan Motivasi Belajar Mengajar. Jakarta, Rajawali Pers.

Setyowati, H. 2006, Keefektifan Penggunaan Pendekatan Kontekstual (Contextual
Teaching Learning) dalam Pembelajaran Biologi Sub Pokok Bahasan Tumbuhan Berbiji di Kelas VII SMPN I Dawe Kudus Tahun Ajaran 2005/2006, Skripsi Sarjana Pendidikan Biologi FMIPA Universitas Negeri Semarang

Sudijono, A. 2014, Pengantar Statistik Pendidikan. Jakarta, Rajawali Press.

Sukardi, H. M. 2012, Evaluasi Pendidikan. Jakarta, Bumi Aksara.

Yulinda, R. dan Ilma, S. 2018, Learning Interest $\mathrm{Og}$ Biology Pre Service Teachers On Contextual Based Plant Morphology Course, JPBI (JURNAL PENDIDIKAN BIOLOGI INDONESIA) Indonesian Journal of Biology Education Vol. 4 No. 2, 2018; pp. 171-178ISSN: 2442-3750 (print); ISSN: 2527-6204 (online) http://ejournal.umm.ac.id/index.php/jp b, Diakses Pada Tanggal 10 Oktober 2019. 